\title{
Taking Divination Seriously: From Mumbo Jumbo to Worldviews and Ways of Life
}

\author{
Sónia Silva \\ Anthropology Department, Skidmore College, 815 North Broadway, Saratoga Springs, NY 12866, USA; \\ ssilva@skidmore.edu
}

Received: 24 August 2018; Accepted: 29 November 2018; Published: 30 November 2018

\begin{abstract}
The peripheral role of divination in religious studies reflects centuries of misrepresentation and depreciation in the textual record. This long history dates back to the travel literature of early modern times, particularly in West Africa, where two stereotypical themes took form: divination as mumbo jumbo, and the diviners as charlatans who shamelessly deceive their credulous clients. These two stereotypical themes persisted through the anthropological discourse about African divination until the 1970s. To undo this long history of misrepresentation and depreciation, a change of analytical focus from reified differences to similar engagement with broad ideas and big questions is in order. By considering a particular case study—basket divination in northwest Zambia—through the theoretical lens of worldviews and ways of life, it becomes possible to take divination seriously and grant it a more central place in religious studies. Four broad, inclusive ideas or big questions emerge from the ethnography of basket divination in northwest Zambia: ontology, epistemology, praxeology, and the place of suffering in human existence.
\end{abstract}

Keywords: divination in discourse and practice; stereotypes about divination; religion and religious studies; worldviews and ways of life; ontology; knowledge and epistemology; praxis and praxeology; pragmatism; existence and suffering; Africa

Because divination, like magic, aims to achieve practical results, it has often been an object of derision and a topic of marginal interest in academia. Beginning with colonial times, a small number of anthropologists became interested in the activity of divination, broadly understood as the use of particular methods to access spiritually authenticated knowledge. ${ }^{1}$ Since the 1990s, the interest in divination picked up again, generating a small but continuous stream of publications. ${ }^{2}$ This said, so much remains unstudied, particularly in religious studies.

In the information page of the special issue "Ethnographies of Worldviews/Ways of Life", Ann Taves and Michael Kinsella propose bringing divination and other often marginalized or ignored practices closer to the center of religious studies, not by expanding the definition of religion, as others have advocated, but by proposing a broader rubric: worldviews and ways of life. A worldview, in their definition, is a complex set of representations related to "big questions," such as ontology, epistemology, axiology, praxeology, and cosmology. Worldviews govern ways of life. Although I would not restrict ways of life to the embodiment of worldviews, I appreciate the idea of "big questions" and the close attention given to particular cases where individuals and groups engage with those questions. I also

1 The best example is E. E. Evans-Pritchard's classic ethnography Witchcraft, Oracles and Magic among the Azande, first published in 1937.

2 See the following interdisciplinary edited volumes, listed here in chronological order: Peek (1991b), Pemberton (2000), Winkelman and Peek (2004), Van Beek and Peek (2013), and Curry (2016). A few books have been published as well, including Silva (2011), Holbraad (2012), and Werbner (2015). Key contributions from the field of religious studies include Grillo (2009), McGraw (2016), and Morgan (2016). 
welcome a theoretical model that sets out to overcome old, negative ideas. In spite of all the excellent work accomplished since the 1990s, the idea of divination continues to conjure up negative images, both outside and within academia. We need to better extricate the phenomenon of divination as it is practiced, lived, and explained in particular times and locations from the pernicious, stereotypical ideas that first took form in the early modern times.

In this spirit, I have divided this historiographic article into four parts. In the first two parts, I sketch key moments in the long history of disrepute and depreciation toward the activity of divining, a somber history that takes us to Africa and Europe. In the last two parts, I propose a change in analytical emphasis from reified religious difference to similarities across practices deemed religious. To this aim, I briefly revisit my work on basket divination in northwest Zambia in the light of four broad ideas that are often shared across different domains of practice: ontology, epistemology, praxeology, and existence. I conclude that basket divination is as committed to a situated definition of the real, truth, action, and existence as any other project that is readily recognized as religious. A sustained focus on these broad concepts enables the recognition of important points of convergence between divination and other activities, thus avoiding the historical trap of depreciation and misrepresentation. But first let us travel backward in time.

\section{The Time of Guinea}

Divination, like magic, has been frowned upon for the longest time. In the Book of Deuteronomy 18:10, we read, "There shall not be found among you anyone who burns his son or his daughter as an offering, anyone who practices divination or tells fortunes or interprets omens ... "In the early Middle Ages, St. Augustine described divination as "a guilty superstition [that springs out] of a baleful fellowship between men and devils" (Augustine 1988, p. 547). This accusation of superstition is still heard today in some religious circles. In the early modern period, however, a shift in tone and ammunition occurred in the negative charges against divination. While the arts of divination continued to be refuted by Christian doctrine, they also came to be seen as a sign of ignorance and inferiority by those who upheld the new idea of scientific progress. From this time period came the earliest derisive descriptions of divination as "mumbo jumbo", and of the diviners as charlatans who shamelessly deceive their credulous clients. Needless to say, these two stereotypical themes-the allocation of human decision-making to random mechanisms, instead of rational thought, and the diviner's avarice and manipulation of their submissive clients through tricks and outward effects-have not entirely vanished from the popular imagination or even academe.

We may find the earliest examples of this progressive yet disparaging stance toward divination in the travel accounts written by northern Europeans in the seventeenth and eighteenth centuries. Consider Jean Barbot, a French tradesman who sailed to Guinea, as West Africa was known at the time, in 1678 and 1682. In his travelogue A Description of the Coasts of North and South Guinea, published in 1732, Barbot described an oracle "fetish" that he saw in south Guinea in these terms:

"The Black's idol was in the shape of a large Bulogna sausage, made of a composition of bugles, glass beads, herbs, clay, burnt feathers, tallow, and threads of the consecrated tree, all pounded and moulded together, having at one end an antick, rough and misshapen human countenance, and was set up in a painted deep calabash, or gourd, among abundance of small stones and bits of wood, with kernels of small nuts, and bones and legs of chickens, or other birds, at it is represented in the cut. All which trash [my emphasis], I was told, serves the Black to know the will of the idol, when he made any request to it, or asked a question, by observing the disposition of those several things, after overturning the gourd or calabash". (Barbot 1732, p. 312)

In addition to describing the "the Black's idol" as a random assemblage of valueless objects-a heap of "trash," as he put it-Barbot engaged the equally predictable theme of the diviner's avarice and his clients' submissiveness. Having mentioned a famous "priest or conjurer," who was said to see 
the past and foretell future events, Barbot asserted: "This instance of the simplicity of those deluded people, shews the subtilty and craftiness of their priests, who can so far blind them that they may not discover their palpable frauds, and keep them in an absolute submission to themselves upon all occasions, so to gratify their insatiable avarice or vanity, and lord it over them as well in civil as in religious affairs" (Barbot 1732, p. 308).

The travel writers who paid lip service to these stereotypes are too many to list. In his widely read bestseller, A New and Accurate Description of the Coast of Guinea, first published in 1705, Willem Bosman, a Dutch tradesman, had the following to say about the "priests" of the Gold Coast, now Ghana, which he often called "feticheers": "The priests, who are generally sly and crafty, encouraged by the stupid Credulity of the People, have all the opportunity in the world to impose the grossest absurdities and fleece their Purses; as they indeed do effectually" (Bosman 1705, p. 152). ${ }^{3}$

The same themes appeared later in the work of armchair European thinkers who never set foot in Africa. Consider Charles de Brosses, the French philosopher who coined the negative term "fetishism." Drawing on the descriptive accounts authored by Bosman and other seamen, de Brosses stated that Africans often consult their "terrestrial divinities," meaning their fetishes, such as talismanic gris-gris, amulets, and oracles. "Not unlike the most brutish nations of the ancient world," de Brosses commented, the Africans reveal "an excess of superstitious stupidity" (de Brosses 2017, p. 46). In the late nineteenth century, the eminent scholar of comparative religion Edward Tylor, who had little to say on the topic of divination otherwise, returned to the theme of randomness in divination, stating: "To a modern educated man, drawing lots or tossing up a coin is an appeal to chance, that is, to ignorance; it is committing the decision of a question to a mechanical process" (Tylor 1920, p. 78).

\section{In Colonial Times}

One would think that, during colonialism, a growing number of anthropologists as well as missionaries and colonial administrators ${ }^{4}$ would have prioritized divination as an object of study. Not only is divination ubiquitous in Africa but it also plays a central role in countless African societies. However, very few of these fieldworkers wrote on the topic, as Philip Peek reports (Peek 1991a, p. 9), and the few among them who did it often fell back on the old derisive themes.

Consider the following comments by British anthropologists, assembled by Peek (1991a, p. 9). According to John Beattie, the diviner knew well that "he was simply putting on an act" (Beattie 1967, p. 64). John Middleton described the speech of a spirit-possessed diviner as "gibberish" (Middleton 1971, p. 271). Geoffrey Parrinder did not believe that anything of value or importance comes out of the diviner's "haphazard methods" (Parrinder 1976, p. 122). In northwest Zambia, where I conducted two years of ethnographic fieldwork on the topic of basket divination, the anthropological scholarship produced during colonialism is not entirely free of the same depreciating comments. When, in response to the colonial legislation against witchcraft and witch-finding, a number of basket diviners put down their baskets and turned to safer methods, such as gazing into reflective surfaces, C.M.N. White, a British colonial officer who was stationed in the region in the 1940s, commented: "we are rapidly getting into the realm of pure charlatanism and confidence tricks at this point, where the semi-sophisticated realizes that he can make a good living out of his more credulous fellows" (White 1948, p. 95). Victor Turner was not immune to the same discourse even though his study of ritual and basket divination in northwest Zambia is pregnant with ethnographic and theoretical insights. In Turner's words, "[the diviner] is not above a certain low cunning at times" (Turner 1975, p. 229), as his clever use of the divining piece known as Chamutang'a illustrates. Taking the form of a human figure in a crouching posture, this piece represents an irresolute person. When Chamutang'a

3 On Willem Bosman, see Pietz (1988).

4 These "practical men" did as much anthropology in this time period as professional anthropologists. See Pels and Salemink (2000, p. 8). 
repeatedly lands atop all the pieces in the basket, diviners know that their clients procrastinated, that they took too long to act. From here, Turner deduced: "it is obvious ... that diviners use Chamutang'a in their professional interest," firmly telling their clients that when someone falls ill they should hurry to a diviner in no time and no matter what—poverty being no excuse-therefore increasing their clientele and their earnings (Turner 1975, p. 222).

Notwithstanding their important contributions to the study of divination, Africa, and anthropology, these authors found it difficult to avoid a dismissive remark, typically in the final pages of their publications, presumably to show their readers that they were not gullible in the slightest. It is therefore no wonder that Evan M. Zuesse opened his article "Divination and Deity in African Religions," published in History of Religions in 1975, with a short statement regretting "the tendency to suppose that the complexity of divinatory ritual ..., as it is disclosed to the Western observer in localized societies, is merely for outward effect- "mumbo jumbo" added by the diviner for heightened impact on clients" (Zuesse 1975, p. 158). ${ }^{5}$

\section{Taking Divination Seriously}

Yet, even during the colonial period, fieldwork yielded rich ethnographic accounts that were increasingly deprived of the older European hocus pocus. While C.M.N. White fell back into the old tendency to denounce the diviner's chicanery and his clients' credulity, his publications are an important contribution to the study of divination and ritual in northwest Zambia. He also helped dispel some of the old stereotypes. Contrary to de Brosses and other earlier writers who denied Africans the notion of transcendence, claiming that they worshiped oracles and other fetishes directly, White showed that the Luvale and related peoples recognize a supreme being or force, which they call Kalunga. They do not formally worship Kalunga or have a ritual or priest of Kalunga, yet Kalunga is clearly a high god that is both a creator and a destroyer (White 1961, pp. 30-31). Prior to evangelization in the early twentieth century, Kalunga was also an otiose god, a god removed from human life and human concerns. ${ }^{6}$ Once they learned about Kalunga, the missionaries in the area quickly adopted this supreme being to render the Christian god in their translations and liturgies (White 1961, p. 30). White concluded: "It is now well recognized that African beliefs about the unseen world and the universe in which they live, including beliefs embracing religion, ancestral spirits, magic and witchcraft, are not merely a collection of superstitions. Rather they form a systematic body of thought in which social and political structure, morals and values, ritual, religion and magic all interlock" (White 1961, p. 28).

We see a similar determination to write against resilient stereotypes, if indirectly, in the work of Turner. Turner may have noted that the basket diviner is not without some cunning at times, but his lucid work helps us undo old errors and negative assumptions. Most importantly, Turner showed that the divination basket is not a random assemblage of "trash," as Barbot succinctly rendered in his view of a West African oracle from the seventeenth century. Instead, focusing on the Ndembu and related peoples of northwest Zambia and neighboring Angola, Turner showed that the divination basket is a system of material symbols and a microcosm of social life. Based on a sample of twenty-eight divinatory pieces and exegetical information provided by five informants, three of them diviners, Turner explained that each object has an array of related meanings (that is, it is polysemic), and that the relevant meaning in each instance is determined by the juxtaposition of those pieces with other pieces in the same material configuration. The unit of meaning is therefore the configuration, and not the individual symbol (Turner 1975, pp. 215-16).

5 It is perhaps not surprising that the term "mumbo jumbo" traces its roots to West Africa. First used in the eighteenth century as the European version of the Mandinka term for a fearful masked dancer that came out during religious ceremonies, its meaning eventually acquired the current broader sense of an involved, nonsensical, and incomprehensible language or activity (Gandhi 2018).

6 On the notion of an otiose god, see Long (1964). 
To add another level of complexity, the basket diviner determines the meaning of each configuration by reading it through the lens of a binary mechanism that takes the form of two parallel lines drawn on opposite sides of the divining basket, one drawn with red clay and the other traced with white kaolin. In some baskets, the white line is traced in between two red lines. Should the pieces land closer to the sides of the basket defined by the red lines, their symbolism takes a greater ominous meaning than they do when they appear closer to the white marks, an auspicious sign. The old, stereotypical descriptions of basket diviners in the act of putting on a show for their clients, dressed in a grass kilt, a coarse necklet, and a feathered head-dress, their torso daubed with white and red stripes (White 1948, p. 94) revealed, to use Jonas Barish's felicitous expression, an "antitheatrical prejudice" (Barish 1981). It also ignored the important fact that the torso stripes followed the same binary chromatic symbolism shown on the sides of divining baskets. Turner unveiled the rich symbolism of basket divination among the Ndembu. ${ }^{7}$ He also stated that basket diviners proceed like Linnaeus, moving from logical conclusion to logical conclusion, revealing to their clients, and all of us, their deep knowledge of their society and their insight into human nature (Turner 1975, pp. 209, 218).

Further strengthening his point that basket divination plays a pivotal role in northwest Zambia, Turner argued that divining is a form of social redress. In his words:

"divination therefore becomes a form of social analysis, in the course of which hidden conflicts between individuals and factions are brought to light, so they may be dealt with by traditional and institutionalized procedures ... It is in the light of this 'cybernetic' function of divination as a mechanism of social redress, that we must consider its symbolism, the social composition of its consultative sessions, and its procedures of interrogation". (Turner 1975, p. 235)

Although this view of diviners as "upholders of tribal morality" (Turner 1975, p. 241) speaks loudly to the influence of structural functionalism in Turner's early work, it is equally possible that Turner offered this positive interpretation as a counterpoint to the frequent negative description of basket diviners as witch-hunters who wrought social havoc in the local communities by turning kin against kin. The British administration promoted this view when they declared witchcraft and witch-finding illegal, de facto turning basket diviners who accepted cases of witchcraft into criminals (White 1948, p. 95). In the European imagination of the early modern period, the word "fetish" encapsulated everything that was presumably wrong and lacking in African societies-from their inability to grasp the notion of transcendence to the haphazard nature of everything they did, from assembling random objects in baskets and calabashes to blindly following the arbitrary rulings of their despotic rulers. By the mid-twentieth century, however, British colonizers had by and large replaced the negative talk about fetishes with the negative talk of witchcraft (Pels 1998).

But Turner's argument also took a different direction imbued with ontological significance. Having compared the basket diviner with Linnaeus, he informed his readers that the basket diviner is a logician of a different kind, since the diviners are possessed by a divination spirit known as Kayongo. As Turner put it, "the bases for his craft are rooted in mystical beliefs, and he is himself a believer" (Turner 1975, p. 229). There is nothing accidental or arbitrary in divination. Not only are the contents of each basket assembled according to their composition, form, and meaning, but the successive configurations of divining pieces as well as the diviner's translation of these visual messages into words are the media through which Kayongo communicates. Divination speech is not gibberish; it is ancestor speech.

\section{Worldviews and Ways of Life}

Although Turner did not develop the important topic of Kayongo in his main interpretive essay on basket divination, "A Preliminary Analysis of Ndembu Divinatory Symbolism" (Turner 1975,

7 Other authors who contributed to the study of basket divination symbolism include Hauenstein (1961) and Rodrigues de Areia (1985), to name a couple. 
pp. 207-242), he let his main informant, Mr. Muchona, speak to that subject in a separate chapter, "Some Kinds and Methods of Ndembu Divination" (Turner 1975, pp. 243-338). We thus gain privileged access into the close relationship that diviners develop with Kayongo over time through the words of a diviner and healer who spoke from his personal experience. In my own work on basket divination in Chavuma, a rural district of northwest Zambia located along the Angolan border, I have returned many times to Mr. Muchona's chapter. Mr. Muchona spoke Ndembu and resided in Mwinilunga district at the time he and Turner met in the mid-1950s. In two years of ethnographic fieldwork conducted between 1995 and 2011, I worked closely with four basket diviners who spoke the Luvale language and resided, at the time of my fieldwork, in Chavuma district, to the southwest of Mwinilunga. ${ }^{8}$ Despite these temporal and geographic distances, however, the lessons that these diviners taught the visiting anthropologists on the topic of Kayongo and basket divination were remarkably similar. In what follows, I interpret my own ethnographic work in Chavuma through the lens of four broad, inclusive ideas assembled by Taves and Kinsella under the rubric of worldviews and ways of life: ontology (Kayongo's presence), epistemology (truthful knowledge), praxeology (resolve and pragmatism), and human existence (the place of suffering in human life). By describing some of the ways in which basket divination engages with these broad ideas and related big questions, as these authors put it, I join them in their efforts to grant divination and other marginalized practices a more central place in the study of religion.

Kayongo is an ancestral manifestation, or lihamba, in the Luvale language spoken in Chavuma. Ancestral manifestations may be male or female, and cause an array of physical symptoms. A displeased ancestor who comes out as lihamba Chipango, for example, causes reproductive disorders to his or her female descendants. Kayongo is the manifestation of a deceased male relative who practiced basket divination during his life time. Kayongo attacks his living descendants in the form of disease, causing them shortness of breath, chest pain, and periods of lunacy. Kayongo hopes in this way to force his living descendants to join the profession of basket divination.

Note here that Kayongo is no different from other mahamba (plural of lihamba) who may attack their living relatives in the form of disease, infertility, or bad luck in hunting. Causing suffering and misfortune is how angry ancestors coerce their descendants to behave according to shared social norms, moral values, and professional expectations. The term Kayongo also refers to the night-long affliction ritual that puts an end to the diviner's suffering by simultaneously curing and initiating him into the divinatory profession. Divination is therefore closer to affliction rituals than Turner presumed, and here we may dispel another common misconception about divination - that it is a ritual of minor religious significance. Turner, however, remained faithful to his opposition between divination and healing rituals, claiming that the divinatory symbolism, being analytical, lacked the "emotional resonance" of healing rituals proper (Turner 1975, pp. 221, 232). As an oracular technique and a way of life, basket divination must be understood within the ontological sphere of ancestral affliction as this sphere is understood in northwest Zambia and elsewhere in Africa. ${ }^{9}$ Here we find our first broad concept, ontology.

It is not possible to understand basket divination apart from the relation that diviners build with Kayongo. This potent lihamba first forces ordinary men to join the divinatory profession by punishing them with disease, and then cures them of their ailments in the course of a night-long affliction ritual. Kayongo is also the source of divinatory knowledge, communicating its truthful statements in the form of chest pain, particular configurations of divining pieces inside the basket, and the translation of these materialized statements into the medium of Luvale words. In this sense, basket divination is predicated on the principle of fluidity across ontological domains. While Kayongo is more typically described as an ancestor spirit, the urgent matters of divination require that this spirit be felt as pain, be seen as meaningfully configured divining pieces, and be heard as words shared with the consulters.

8 For my own work on basket divination, see Silva $(2011,2013,2014,2018)$. See also de Boeck and Devisch (1994) for a relatively recent study of basket divination in the southwest corner of the Democratic Republic of the Congo.

9 John M. Janzen's work on the so-called rituals of affliction, or Ngoma, meaning "drum," across Central and Southern Africa is of great interest in this regard (Janzen 1992). 
Now, this emphasis on ontological fluidity is never reduced to a philosophical debate on the categories of being and the meaning of the real. Diviners reach out to Kayongo and activate its presence in order to deliver truthful knowledge to their clients who suffer. Here we encounter the second and third broad concepts or ideas, epistemology and praxeology. Maybe their clients lost a loved one unexpectedly or a relative of theirs is struggling with infertility or a wasting sickness. By correctly identifying the cause of their problem and prescribing a successful treatment, diviners trust that the divinatory knowledge helps their clients heal. Action leads to knowledge, and knowledge facilitates healing. I mentioned earlier that basket divination is oftentimes associated with witchcraft accusations. Basket divination, however, sends out positive messages to the consulters: they ought not fail to honor their ancestors, they ought not disrespect and injure one another; and they ought not lose hope in the darkest hours. While basket diviners do not promise or even boast that they can end human suffering-basket divination is built on the assumption that humanity is equally capable of love and tenderness and hate and cruelty-they assure their clients that they are able to identify the cause of their problems and the way to overcome them. They also serve as a positive reminder that while life entails suffering - the fourth broad concept of human existence-it is not always in vain. Diviners are, after all, the living proof of this profound truth. Similarly to many of their clients who fall prey to their angry ancestors, diviners once suffered at the hands of Kayongo, a notoriously cruel and merciless lihamba. Thanks to their own suffering, however, diviners are able to divine for others who are also suffering, and maybe even commiserate with them and lower their fees.

Divination is therefore a very serious practical matter for both diviners and their clients. The séance participants are unlikely to engage in a philosophical discussion about the real or to pick up an abstract discussion about truthful knowledge that remains disconnected from the particulars of the divination case at hand. They are also unlikely to display an ecstatic stance toward Kayongo, and to reveal an attitude of passivity during divination, blindly accepting the truth revealed. Everyone has heard of séances in which the consulters contested and invalidated the oracular truth by simply interrupting the diviner and taking off. The consulters may also decide to approach other basket diviners or, more often, other diviners who are known to operate different material apparatus, such as mwishi (a pounding pole) or chitaho (a water-filled mortar). Those who can afford it may travel to the provincial capital of Solwezi to consult a "TV screen." Consulters measure the value of each oracular result against the particulars of their case and the healing plan prescribed. Because requesting the services of a diviner is often costly, the sufferers weigh their options. Needless to say, divining costs vary widely across Africa and the entire world. In Africa, some diviners charge heavy sums, whereas others charge nothing. In northwest Zambia, the fees charged by basket diviners in cases of death may leave the consulters indebted for years. Among the Lobi of Burkina Faso, however, diviners earn close to nothing (Meyer 1991, p. 94). This said, as Michael Jackson notes, divination is everywhere enveloped in a pragmatic attitude toward life and events, an attitude that prioritizes action over inertia, and engagement over detachment (Jackson 2012, pp. 44-45). Pragmatism infuses the way of life of divination with resolve, relevance, and urgency. It also brings us back to the broad concept of praxeology.

Not everyone, however, sees this pragmatic attitude with the same eyes. In Chavuma, it has earned the diviners as well as their clients a bad reputation. Some Christians proclaim that true "believers" should cultivate an inner relationship with Kalunga, the Luvale word for the Christian high god, instead of turning to basket diviners who capitalize on their suffering and put on a ridiculous show that reveals nothing and heals no one. Yet such a view, which is surely as valid and legitimate as that of the basket consulters, misses a critical point. In the midst of suffering, people are likely to adopt what we may call, borrowing from Susan Whyte, a pragmatics of uncertainty (Whyte 1997). They may reach out to Kalunga and local healers first; if the health of their sick relative deteriorates, they may take their relative to the mission hospital run by the Christian Missions in Many Lands, or CMML, located in the township of Chavuma; if that fails, they may reach out to diviners. There is nothing inherently nonreligious or insufficiently religious, as Zuesse puts it (Zuesse 1975, p. 158), about 
divination. Needless to say, there is nothing nonreligious or insufficiently religious about pragmatism, performance, and economics either.

We have much work to do. Ever since European seamen arrived in Guinea and described the African oracles and other so-called fetishes as the antithesis of their monotheistic religion, a number of scholars have attempted to grant divination some kind of religiosity while at the same time continuing to belittle it as a minor practice. Divination is deemed closer to magic and witcheraft than it is to religion proper. Divination rituals are said to differ from healing rituals, the rituals proper, as Turner claimed, and so forth. Looking backward, we see a growing commitment to deepen understanding, to systematize and classify, to make sense of cultural and religious differences by drawing boundaries and accentuating differences. Yet this hard work of sorting out differences and drawing boundaries has prevented us from exploring the worldviews and ways of life that become hidden and distorted under the lens of the hierarchical categories so often used to classify religion: the high god religions on one side, the folk religions on the opposite side (Jackson and Piette 2015, p. 13; Taves 2009, p. 6). This hierarchical stance blinds us to the similarities that prevail across lines of difference, to the possibility of a common ground. In its commitment to a situated definition of the real, truth, action, and existence, basket divination shows that divination systems in Africa, and elsewhere, are as likely to engage with broad concepts and ideas as other projects more readily described as religious. Any serious discussion about divination must therefore start from the shared premise that divination participates in broader conversations and addresses vital matters.

Funding: This research received no external funding.

Conflicts of Interest: The authors declare no conflicts of interest.

\section{References}

Augustine, St. 1988. On Christian Doctrine. In A Select Library of Nicene and Post-Nicene Fathers of the Christian Church. Translated by J. F. Shaw. Edited by Philip Schaff. Edinburgh: T\&T Clark, vol. 2, pp. 519-97.

Barbot, Jean. 1732. A Description of the Coasts of North and South Guinea. In A Collection of Voyages and Travels. London: vol. 5.

Barish, Jonas. 1981. The Antitheatrical Prejudice. Berkeley: University of California Press.

Beattie, John. 1967. Consulting a Nyoro Diviner: The Ethnologist as Client. Ethnology 6: 57-65. [CrossRef]

Bosman, Willem. 1705. A New and Accurate Description of the Coast of Guinea. London: Printed for Sir James Knapton. Curry, Patrick, ed. 2016. Divination: Perspectives for a New Millennium. London: Routledge.

de Boeck, Filip, and René Devisch. 1994. Ndembu, Luunda and Yaka Divination Compared: From Representation and Social Engineering to Embodiment and Worldmaking. Journal of Religion in Africa 24: 98-133. [CrossRef]

de Brosses, Charles. 2017. On the Worship of Fetish Gods; or, A Parallel of the Ancient Religion of Egypt with the Present Religion of Nigritia. In The Returns of Fetishism. Edited by Rosalind C. Morris and Daniel H. Leonard. Translated by Daniel H. Leonard. Chicago: University of Chicago Press, pp. 44-132. First published 1760.

Gandhi, Lakshmi. 2018. Unmasking the Meaning and Marital Disputes Behind Mumbo Jumbo. NPR. Available online: https:/ / www.npr.org/sections / codeswitch/2014/05/31/317442320/unmasking-the-meaning-andmarital-disputes-behind-mumbo-jumbo (accessed on 23 November 2018).

Grillo, Laura S. 2009. Divination: Epistemology, Agency, and Identity in Contemporary Urban West Africa. Religion Compass 3: 921-34. [CrossRef]

Hauenstein, Alfred. 1961. La Corbeille aux Osselets Divinatoires des Tchokwe (Angola). Anthropos 56: 114-57.

Holbraad, Martin. 2012. Truth in Motion: The Recursive Anthropology of Cuban Divination. Chicago: Chicago University Press.

Jackson, Michael. 2012. How to Do Things with Stones. In Lifeworlds: Essays in Existential Anthropology. Chicago: University of Chicago Press, pp. 31-50.

Jackson, Michael, and Albert Piette. 2015. Introduction: Anthropology and the Existential Turn. In What is Existential Anthropology? Edited by Michael Jackson and Albert Piette. New York: Berghahn, pp. 11-29.

Janzen, John M. 1992. Ngoma: Discourses of Healing in Central and Southern Africa. Berkeley: University of California Press. Long, Charles H. 1964. African High God: History and Religious Experience. History of Religions 3: 328-42. [CrossRef] 
McGraw, John J. 2016. Maya Divination: Ritual Techniques of Distributed Cognition. Journal of Cognition and Culture 16: 177-98. [CrossRef]

Meyer, Piet. 1991. Divination among the Lobi of Burkina Faso. In African Divination Systems: Ways of Knowing. Edited by Philip Peek. Bloomington: Indiana University Press, pp. 91-100.

Middleton, John. 1971. Oracles and Divination among the Lugbara. In Man in Africa. Edited by Mary Douglas and Phyllis M. Kaberry. New York: Anchor Books, pp. 262-78.

Morgan, David. 2016. Material Culture of Divination. Material Religion 12: 505-6. [CrossRef]

Parrinder, Geoffrey. 1976. African Traditional Religion. New York: Harper and Row.

Peek, Philip M. 1991a. The Study of Divination: Present and Past. In African Divination Systems: Ways of Knowing. Edited by Philip Peek. Bloomington: Indiana University Press, pp. 1-22.

Peek, Philip, ed. 1991b. African Divination Systems: Ways of Knowing. Bloomington: Indiana University Press.

Pels, Peter. 1998. The Magic of Africa: Reflections on a Western Commonplace. African Studies Review 41: 193-209. [CrossRef]

Pels, Peter, and Oscar Salemink. 2000. Introduction: Locating the Colonial Subjects of Anthropology. In Colonial Subjects: Essays on the Practical History of Anthropology. Edited by Peter Pels and Oscar Salemink. Ann Arbor: The University of Michigan Press, pp. 1-52.

Pemberton, John, ed. 2000. Insight and Artistry in African Divination. Washington, DC: Smithsonian Institution Press.

Pietz, William. 1988. The Problem of the Fetish, IIIa: Bosman's Guinea and the Enlightenment Theory of Fetishism. RES 16: 105-24. [CrossRef]

Rodrigues de Areia, Manuel L. 1985. Les Symboles divinatoires: Analyse socio-culturelle d'une technique de divination des Cokwe de l'Angola (Ngombo ya Cisuka). Coimbra and Portugal: Centro de Estudos Africanos, Universidade de Coimbra.

Silva, Sónia. 2011. Along an African Border: Angolan Refugees and Their Divination Baskets. Philadelphia: University of Pennsylvania Press.

Silva, Sónia. 2013. Remarks on Similarity in Ritual Classification: Affliction, Divination, and Object Animation. History of Religions 53: 151-69. [CrossRef]

Silva, Sónia. 2014. Mind, Body and Spirit in Basket Divination: An Integrative Way of Knowing. Religions 5: 1175-87. [CrossRef]

Silva, Sónia. 2018. Temps, prédiction et avenir dans la divination rétrospective. Étude d'un cas en Zambie. Anthropologie et Sociétés 42: 107-26. [CrossRef]

Taves, Ann. 2009. Religious Experience Reconsidered: A Building-Block Approach to the Study of Religion and Other Special Things. Princeton: Princeton University Press.

Turner, Victor. 1975. Revelation and Divination in Ndembu Ritual. Ithaca: Cornell University Press.

Tylor, Edward B. 1920. Primitive Culture. London: John Murray, vol. 1. First published 1871.

Van Beek, Walter E. A., and Philip M. Peek, eds. 2013. Reviewing Reality: Dynamics of African Divination. Berlin: Lit Verlag.

Werbner, Richard. 2015. Divination's Grasp: African Encounters with the Almost Said. Bloomington: Indiana University Press.

White, Charles Matthew Newton. 1948. Witchcraft, Divination, and Magic among the Balovale Tribes. Africa 18: 81-104. [CrossRef]

White, Charles Matthew Newton. 1961. Elements in Luvale Beliefs and Rituals. Manchester: Manchester University Press.

Whyte, Susan Reynolds. 1997. Questioning Misfortune: The Pragmatics of Uncertainty in Eastern Uganda. Cambridge: Cambridge University Press.

Winkelman, Michael, and Philip M. Peek. 2004. Divination and Healing: Potent Vision. Tucson: Arizona University Press.

Zuesse, Evan M. 1975. Divination and Deity in African Religions. History of Religions 15: 158-82. [CrossRef]

(C) 2018 by the author. Licensee MDPI, Basel, Switzerland. This article is an open access article distributed under the terms and conditions of the Creative Commons Attribution (CC BY) license (http:/ / creativecommons.org/licenses/by/4.0/). 